\title{
Minimal residual disease monitoring by R0- PCR of Ig/TCR rearrangements: an effective method to predict relapse in children with acute lymphoblastic leukemia after alloge- neic hematopoietic stem cell transplantation
}

\begin{abstract}
Victoria A. Lavrinenko ${ }^{1}$, Alexandr N. Meleshko ${ }^{1}$, Dmitry V. Lutskovich ${ }^{1}$, Yulia E. Mareiko ${ }^{1}$, Dmitriy V. Prudnikov ${ }^{1}$, Mikhail V. Belevtsev ${ }^{1}$, Olga V. Aleynikova ${ }^{1}$, Ildar M. Barkhatov ${ }^{2}$, Boris V. Afanasyev ${ }^{2}$

${ }^{1}$ The Republican Research and Practical Center of Pediatric Oncology, Hematology and Immunology, Minsk, Republic of Belarus ${ }^{2}$ R. Gorbacheva Memorial Research Institute of Children Oncology, Hematology and Transplantation at the First St. Petersburg State I. Pavlov Medical University, St. Petersburg, Russian Federation
\end{abstract}

Dr. Viktoria A. Lavrinenko, The Republican Research and E-mail: lavrinenkovictoria@gmail.com

Practical Center of Pediatric Oncology, Hematology and Immunology, Borovlany, Frunzenskaya St. 43, 223053,

Minsky District, Minsk, Republic of Belarus

Citation: Lavrinenko VA, Meleshko AN, Lutskovich DV et al. Minimal residual disease monitoring by RQ-PCR of Ig/TCR rearrangements: an effective method to predict relapse in children with acute lymphoblastic leukemia after allogeneic hematopoietic stem cell transplantation. Cell Ther Transplant 2018; 7(4): 47-60

\section{Summary}

At the present time, clinical relapses remain the major cause of treatment failure in children with acute lymphoblastic leukemia (ALL) treated by allogeneic hematopoietic stem cell transplantation (allo-HSCT). So far, the requirements for precise quantification of minimal residual disease (MRD) after HSCT were did not confirmed. The aim of this study was to evaluate the impact of MRD assays on management and prediction of outcomes after allo-HSCT.

\section{Patients and methods}

The Ig/TCR markers were identified for MRD monitoring in 37 (82.2\%) of 45 patients. Presence of high-level MRD after allo-HSCT was an unfavorable prognostic factor for the clinical outcome. The 3-year cumulative incidence (CI) of relapse in the patients with negative MRD vs MRD levels of $\leq 10^{-3}$, and $>10^{-3}$ proved to be $10.7 \pm 7.4 \% ; 14.6 \pm 14.6 \%$, and $100 \%$, respectively $(\mathrm{p}<0.0001)$. Event-free survival (EFS) was $66.6 \pm 11.4 \%$ vs $43.8 \pm 18.8 \%$ vs $0 \%(\mathrm{p}=0.0012)$ at the respective MRD levels, whereas overall survival (OS) was $83.6 \pm 8.8 \%$ vs $57.1 \pm 18.7 \%$ vs $0 \%(\mathrm{p}=0.0083)$, resp., for undetectable, $\leq 10^{-3}$, and $>10^{-3} \mathrm{MRD}$ levels. MRD positivity combined with increasing mixed chimerism (MC) was followed by relapse in almost all cases. MRD clearance was more often observed in patients with full donor chimerism (FDC) having graft-versus-host disease (GvHD) posttransplant, or after donor lymphocyte infusion.

\section{Conclusion}

Positive MRD after HSCT is an unfavorable factor for OS and EFS, being associated with ALL re-occurrence. We identified the high-risk group for relapses after allo-HSCT among ALL patients, i.e., those cases which showed MRD positivity with mixed chimerism (MC) and absence of GvHD, and/or had MRD $>10^{-3}$.

\section{Keywords}

Acute lymphoblastic leukemia, hematopoietic stem cell transplantation, minimal residual disease, donor chimerism, relapse risk. 


\section{Introduction}

Allo-HSCT is a well-defined treatment mode for high-risk acute lymphoblastic leukemia (ALL) [1]. However, relapse still remains the major cause of treatment failure in children with ALL, even among patients who received transplantation during hematologic remission [2-4]. High risk of relapses after allo-HSCT arises, mostly, due to selection of the patients with signs of poor clinical prognosis (refractory to chemotherapy, unfavorable cytogenetic or molecular genetic alterations) [5,6], whereas the patients with more favorable prognosis undergo standard chemotherapy treatment $[1,7]$. The relapses occur in $30-35 \%$ of patients with ALL and it is one of the most common causes of mortality after allo-HSCT $[2,3,8]$. Survival of patients who experienced relapse is about 3-19\% depending on the time between allo-HSCT and relapse [9]. In the case of clinical posttransplant relapse further treatment options are limited and often ineffective $[10,11]$. For example, a second allo-HSCT can give a chance to cure such patients, but it is associated with high morbidity and mortality. Donor lymphocyte infusion (DLI) has a limited success if it is started during hematological relapse [12]. At the same time, immunotherapy at the stage of early relapse (before hematological manifestation), when the leukemia clone is still small, is more effective than relapse treatment [12-15]. Therefore, the study of early signs of disease recurrence is particularly important.

The early signs of impending ALL relapse after allo-HSCT are usually detected by MRD monitoring using the following means: 1) flow cytometry of leukemia-associated immunophenotype, or quantitative real-time PCR of chimeric oncogenes, or clonal rearrangements of immunoglobulin molecules, or T-cell receptor genes (Ig/TCR-PCR) [16-18]; 2) donor chimerism monitoring $[19,20]$.

A clone of ALL cells originating from a single primary-transformed cell carries identical Ig/TCR rearrangements in all the malignant cells. Therefore, the rearrangements detected in ALL samples at diagnosis could serve as specific molecular markers for MRD monitoring. Ig/TCR rearrangements allow MRD monitoring in the vast majority of ALL patients, and comparing the results after allo-HSCT [21].

MRD monitoring in pediatric ALL by Ig/TCR rearrangements has widely been accepted as a reliable prognostic factor of relapse during chemotherapy and before allo-HSCT [1]. However, its application after allo-HSCT has been less clearly defined and still controversial. The significance of precise quantification of MRD after transplantation is not completely established. The aim of the study was to evaluate the impact of quantitative MRD on outcomes of allo-HSCT.

\section{Patients and methods}

Our study included 45 patients with ALL or biphenotypic AL who underwent the first allo-HSCT at the Center for Pediatric Oncology, Hematology and Immunology from 2010 to 2017. Initial screening for Ig/TCR clonal rearrangements was performed in all the patients. MRD monitoring using Ig/TCR targets was performed in 35 of them (eight patients had no target markers, 1 had no primary engraftment, no sample material was obtained after 1 alloHSCT). Basic characteristics of 35 patients with ALL/biphenotypic AL enrolled in the posttransplant MRD studies are listed in Table 1. The recipient age at the time of transplantation was 2-25 (median 11) years. All parents or guardians signed the informed consent. All the patients received myeloablative conditioning (MAC), except of one with Nijmegen syndrome/ALL who underwent a reduced-intensity conditioning regimen (RIC).

Table 1. Characteristics of patients with ALL and biphenotypic $A L(n=35)$ included in the MRD study after allo-HSCT

\begin{tabular}{|c|c|}
\hline Characteristic & Value \\
\hline Recipient age, median (range), years & $11(2-25)$ \\
\hline Donor age, median (range), years* & $27(1-48)$ \\
\hline Recipient gender: male/female, n (\%) & $23 / 12(66 \% / 34 \%)$ \\
\hline Donor: male/female, n (\%) & $23 / 12(66 \% / 34 \%)$ \\
\hline \multicolumn{2}{|l|}{ Diagnosis, n (\%) } \\
\hline \multicolumn{2}{|l|}{ ALL } \\
\hline complete remission (CR) 1 & 6 \\
\hline CR2 & 21 \\
\hline$C R \geq 3$ & 5 \\
\hline non-remission & 1 \\
\hline Nijmegen syndrome / ALL, CRI & 1 \\
\hline biphenotypic AL, CR1 & 1 \\
\hline \multicolumn{2}{|l|}{ Donor type, n (\%) } \\
\hline MSD & $9(26 \%)$ \\
\hline MUD & $16(46 \%)$ \\
\hline MMFD & $3(8 \%)$ \\
\hline MMUD & $7(20 \%)$ \\
\hline \multicolumn{2}{|l|}{ Stem cell source, n (\%) } \\
\hline Bone marrow & $24(69 \%)$ \\
\hline Peripheral blood stem cells & $11(31 \%)$ \\
\hline \multicolumn{2}{|l|}{ Conditioning } \\
\hline MAC based on total body irradiation & $28(80 \%)$ \\
\hline MAC based on busulfan/treosulfan & $5(14 \%)$ \\
\hline$M A C$, others & $1(3 \%)$ \\
\hline $\mathrm{RIC}$ & $1(3 \%)$ \\
\hline Cell dose, median (range), $\times 10^{8} / \mathrm{kg}$ & $4.3(1.4-14.4)$ \\
\hline CD34+ cell dose, median (range), $\times 10^{6} / \mathrm{kg}$ & $4.8(0.2-16.9)$ \\
\hline T-depletion, n (\%) & $5(14 \%)$ \\
\hline \multicolumn{2}{|l|}{ GvHD prophylactic, n (\%) } \\
\hline CNI & $13(37 \%)$ \\
\hline $\mathrm{CNI}+\mathrm{MTX}$ & 20 (57\%) \\
\hline $\mathrm{CNI}+\mathrm{MMF}$ & $1(3 \%)$ \\
\hline MMF & $1(3 \%)$ \\
\hline
\end{tabular}

For MRD assays, bone marrow (BM) and peripheral blood (PB) samples were collected on days $+30,+60,+100,+180$, +365 after alloHSCT, and every six months thereafter. Mononuclear BM cells were isolated in the Histopaque density gradient (Sigma-Aldrich, USA). DNA extraction was carried out by phenol-chloroform method. DNA quality and concentration was evaluated with a NanoDrop 2000c spectrophotometer (ThermoFisher Scientific, USA).

Genomic DNA samples at diagnosis were screened by PCR for clonal $\mathrm{IgH}$, IgK immunoglobulin and rearrangements of TCRD, TCRG, TCRB genes. DNA amplification was performed with primers, recommended by BIOMED-1 Concerted Action [22] for IgK and TCRG genes, and a report by Chim et al. for IgH gene [23]. The TCRD gene was amplified 
according to Taube et al. [24], and TCRB by BIOMED-2 Concerted Action [21]. Further on, the specific PCR products were evaluated by heteroduplex analysis by polyacrylamide gel technique, then being cut from the gels, purified and sequenced in the ABI PRISM 3130 Genetic Analyzer (Applied Biosystems, USA) in both directions. Detailed description of the detection procedure of different Ig/TCR rearrangements in ALL was reported in our previous publications $[25,26]$. Allele-specific oligonucleotides (ASO) primers were selected to cover the $\mathrm{N}$ region of rearrangement, specifically, for the 3' end of primer. Secondary structures were avoided. At least two different ASO-primers were designed for each rearrangement point and tested, in order to choose the best system for MRD quantification.

ASO-primers and germline TaqMan probe approach were applied for RQ-PCR analysis in CFX96 machine (Bio-Rad, USA). PCR amplification was performed in $20 \mu \mathrm{L}$ reaction mix with TaqMan Universal PCR Master Mix (Applied Biosystems, USA), $500 \mathrm{ng}$ of genomic DNA, $500 \mathrm{ng}$ of each primer and $150 \mathrm{ng}$ of fluorescent TaqMan probe labeled with 3'FAM, 5'BHQ. The panel of germline primers and probes was published elsewhere [27]. For MRD quantification, we prepared serial ten-fold dilutions of diagnostic DNA in polyclonal controls to make a standard curve construction. To normalize the individual results, the same samples were amplified with primers for albumin reference gene [28]. A standard curve for the albumin gene was plotted with diagnostic DNA serially diluted in water. Standard Quantity (SQ, mean of triplicate) was automatically generated by CFX96 based on standard curve for both albumin and target. Interpretation of MRD analysis results was performed in accordance with the guidelines published by the European Study Group on MRD detection [29].

RNA was isolated from the BM mononuclear cells with TRIzol reagent (Thermo Fisher Scientific, USA). MRD monitoring based on measuring expression of chimeric oncogenes TEL-AML1, BCR-ABL1, MLL1-AF4 was performed by quantitative real-time PCR of the cDNA. The real-time PCR was performed in $25-\mu \mathrm{l}$ volume containing $2 \mathrm{x}$ TaqMan Universal PCR Master Mix (Applied Biosystems, USA), 300 $\mathrm{nM}$ primers, $200 \mathrm{nM}$ TaqMan probes and $5 \mu \mathrm{l}$ of cDNA or standards. Commercial standards (Qiagen, Germany) were used for calibration of absolute gene copy numbers. The PCR conditions were as follows: $2 \mathrm{~min}, 50^{\circ} \mathrm{C} ; 10 \mathrm{~min}, 95^{\circ} \mathrm{C} ; 50$ cycles $\left(95^{\circ} \mathrm{C}, 15 \mathrm{sec} ; 60^{\circ} \mathrm{C}, 60 \mathrm{sec}\right)$.

MRD detection was also performed by multiparametric flow cytometry (FC) of mononuclear cell suspensions (1 million cells/mL, $100 \mu \mathrm{l}$ ). A panel of monoclonal antibodies conjugated with fluorescent labels FITC, PE, PC5, PC7 (Beckman Coulter, USA). In addition, we used reagents for fixation and permeabilization (Becton Dickinson, USA) for detection of intracellular antigens. Following incubation and staining, the cells were washed once in phosphate buffer saline with subsequent fixation in $1 \%$ paraformaldehyde. FC-analysis was carried out with the Navios flow cytofluorimeter (Beckman Coulter, USA) using the CXP program.

Donor chimerism was determined by real-time PCR of InDel markers and multiplex PCR of short tandem repeats (STR) in $\mathrm{BM}$ and/or $\mathrm{PB}$ on $+30,+45,+60,+80,+100,+140,+180$,
$+245,+365$ days after allo-HSCT and, thereafter, every six months. In case of mixed chimerism (MC), the studies were conducted more often. AmpFlSTR ${ }^{\circledast}$ SGM Plus ${ }^{\oplus}$ PCR Amplification Kit (ABI, UK) was used for amplification of STR markers, PCR products were separated by capillary electrophoresis using 3130 Genetic Analyzer (Applied Biosystems, USA). Distinct alleles were identified by means of GeneMapper software (Applied Biosystems, USA). InDel-PCR was performed as previously described [30-32]. Full donor chimerism (FDC) was defined as $>99 \%$ donor cells, and mixed chimerism was accepted at 5-99\% donor cells.

Statistical evaluation was performed by non-parametric methods using the STATISTICA approach. Overall survival was defined as the time period between allo-HSCT and death, or to the last observation date. Treatment-related mortality (TRM) was defined as a death in complete remission state (CR) without preceding relapse, from any causes associated with HSCT procedure. Event-free survival (EFS) was determined as survival without TRM, relapse, rejection, or secondary tumor. The time to clinical events (relapse, TRM, GVHD) was measured from the date of alloHSCT. Kaplan-Meier estimates were performed to predict probabilities for overall survival and EFS [33]. The log-rank test was used for comparisons. Cumulative incidence (CI) curves were calculated to assess incidence of relapse (CIR) and TRM [34]. Gray's test was used for comparisons of CIs [35]. Fisher's exact test was applied in order to compare the patients' categorical data. The results of statistical evaluation were considered significant at $\mathrm{p}<0.05$.

\section{Results}

\section{Survival of patients with different MRD status after allo-HSCT}

Ig/TCR clonal rearrangements were identified for 37 of 45 patients $(82.2 \%)$. Chimeric oncogenes were determined only in 10 (22\%) of 45 patients: 5 (11.1\%) with $M L L-A F 4$; 4 BCR-ABL1-positive cases (8.9\%); one patient (2.2\%) with TEL-AML1. MRD monitoring by Ig/TCR rearrangements was performed after 35 allo-HSCT that were included into the analysis. The median follow-up of the patients surviving after allo-HSCT was 3.6 years.

MRD status according to Ig/TCR target was negative in 21 $(60 \%)$ patients, and only two of them $(9.5 \%)$ relapsed. Positive MRD was detected in 14 (40\%) patients, 7 (50\%) of them had isolated bone marrow relapse. The three-year CI of relapse was higher in the patients with positive MRD at any time after allo-HSCT $(58.3 \pm 16.2 \%)$ as compared to the patients with negative MRD (10.7 $\pm 7.4 \%), p=0.0042$ (Fig. 1). Overall survival and EFS were significantly lower in cases of positive MRD (33.2 $\pm 14.4 \%$ vs $83.6 \pm 8.8 \%$, $\mathrm{p}=0.008$, and $18.9 \pm 11.7 \%$ vs $66.6 \pm 11.4 \%, \mathrm{p}=0.002)$.

In all six patients who reached high MRD levels $\left(>10^{-3}\right)$, we observed recurrence of the disease. Only one (16.7\%) patient relapsed of six children with intermediate MRD levels $\left(10^{-4}-10^{-3}\right)$. Two patients with MDR level $<10^{-4}$ retained their CR state. Generally, in cases of positive MRD, the patients with relapse showed higher levels of preceding MRD $\left(1.6^{\star} 10^{-1}-2.7^{\star} 10^{-4}\right)$, than the relapse-free patients $\left(<10^{-5}-10^{-3}\right)$, 

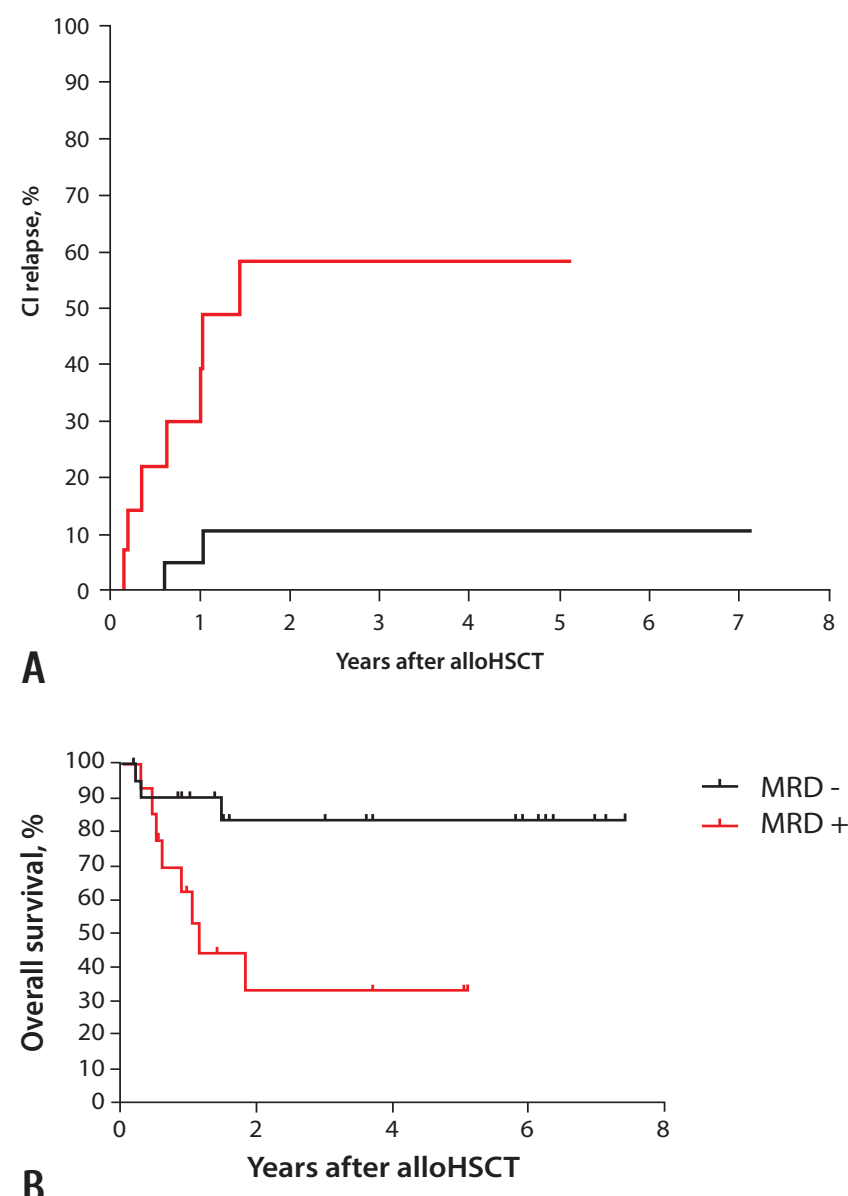

B

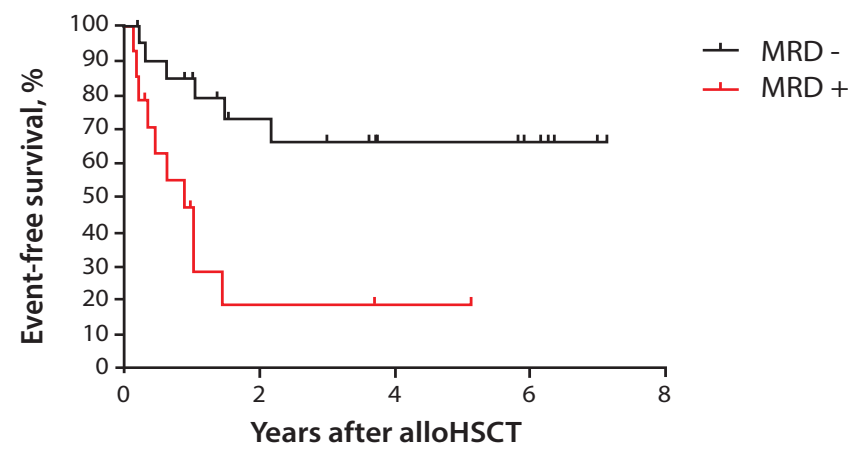

C

Figure 1. Probability (CI) of relapse (A), OS (B) and EFS values $(C)$ in the patients with ALL/biphenotypic AL according to MRD status after allo-HSCT

as seen from Table 2. The three-year cumulative incidence (CI) of relapse for the patients with non-detectable MRD, with MRD $\leq 10^{-3}$, and $>10^{-3}$ was, respectively, $10.7 \pm 7.4 \%$ vs $14.6 \pm 14.6 \%$ vs $100 \%(\mathrm{p}<0.0001)$. Overall survival rates (OS) were $83.6 \pm 8.8 \%$ vs $57.1 \pm 18.7 \%$ vs $0 \%(\mathrm{p}=0.0083)$, and $\mathrm{EFS}$ rates were $66.6 \pm 11.4 \%$ vs $43.8 \pm 18.8 \%$ vs $0 \%(\mathrm{p}=0.0012)$, respectively (Fig. 2).

In two patients, positive MRD was not found in BM cells before relapse. One patient had extramedullary relapse (EMR) in the central nervous system (CNS). In the second patient, a loss of Ig/TCR target was observed in hematological BM relapse.

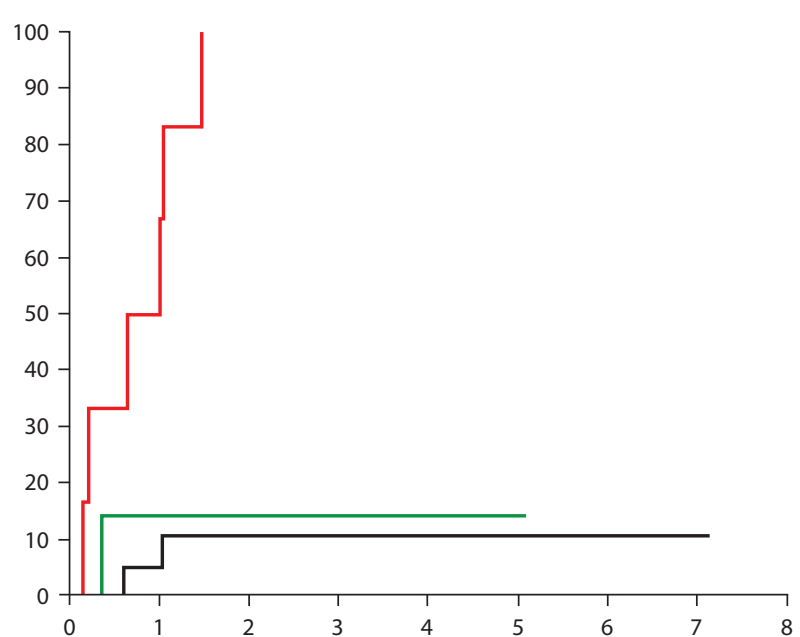

A

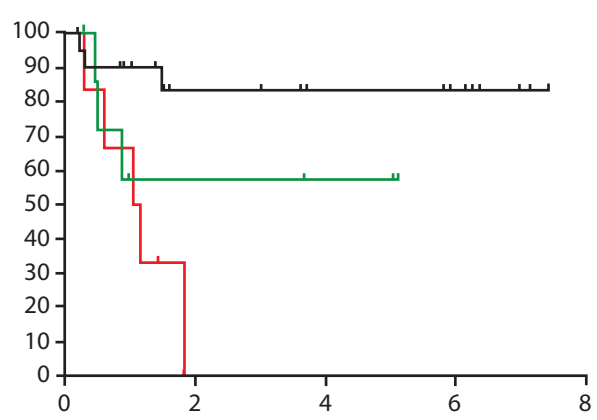

B

Years after alloHSCT

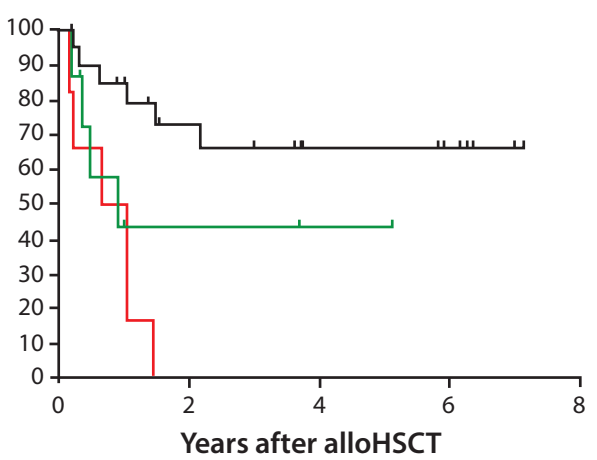

C

Figure 2. Probability (CI) of relapse (A), OS (B), and EFS (C) in patients with ALL/biphenotypic AL according to MRD levels after alloHSCT. Curves are designated black (MRD -); green (MRD $\left.>10^{-3}\right)$; or red $\left(\mathrm{MRD}<10^{-3}\right.$ )

MRD monitoring with $\mathrm{Ig} / \mathrm{TCR}$ rearrangements in $\mathrm{BM}$, along with $\mathrm{PB}$, was performed in 10 patients. In seven cases (70\%), positive MRD was detected before relapse in both BM and $\mathrm{PB}$. In three patients, MRD was detected in BM only, one of them relapsed. In this patient, MRD was still not detected in $\mathrm{PB}$ at the time of relapse.

\section{Comparison of MRD results obtained by different targets/methods}

In nine patients, MRD was monitored by Ig/TCR rearrangements, as well as expression of $B C R-A B L 1(\mathrm{n}=4), M L L-A F 4$ $(\mathrm{n}=4), T E L-A M L 1(\mathrm{n}=1)$. In only one case, the results were 
Table 2. Time dynamics of MDR in patients with ALL

\begin{tabular}{|c|c|c|c|c|c|c|c|}
\hline $\begin{array}{l}\mathrm{Pa}- \\
\text { tient }\end{array}$ & MRD level & MRD increase & $\begin{array}{l}\text { MRD } \\
\text { clearance }\end{array}$ & DLI & $\begin{array}{l}\text { aGvHD/ } \\
\text { cGvHD } \\
\text { (grade) }\end{array}$ & Chimerism & Outcome \\
\hline 1 & $<10^{-5}-10^{-4}$ & $\begin{array}{l}\text { yes; from }+30\left(^{(\star}\right) \text { to }+60 \text { day } \\
\text { per llg }\left(^{\star \star \star}\right)\end{array}$ & $\begin{array}{l}\text { yes, after }+100 \\
\text { day }\end{array}$ & no & $3 /$ no & $\begin{array}{l}\text { Decreasing } \\
\text { MC/FDC }\end{array}$ & alive (5 years) \\
\hline 2 & $<10^{-4}-4^{\star} 10^{-4}$ & $\begin{array}{l}\text { yes; negative on }+30 \text { day, from } \\
+60 \text { day growth up to } 4^{\star} 10^{-4} \text { on } \\
+100 \text { day (**) }\end{array}$ & $\begin{array}{l}\text { yes, after }+150 \\
\text { day }\end{array}$ & no & $4 /$ ext & FDC & TRM (165 day) \\
\hline 3 & $10^{-4}-10^{-3}$ & $\begin{array}{l}\text { yes; negative on }+30 \text { day, from } \\
+60 \text { day growth up to } 10^{-3} \text { on } \\
+100 \text { day }(* *)\end{array}$ & $\begin{array}{l}\text { yes, after }+100 \\
\text { day }\end{array}$ & no & $3 /$ ext & FDC & alive ( 3,7 years) \\
\hline 4 & $2.2^{*} 10^{-4}$ & 1 point & - & no & 1 & FDC & alive (95 days) \\
\hline 5 & $\begin{array}{l}<10^{-4} ; \\
\text { after rejection } \\
2.3 * 10^{-6}-10^{-5}\end{array}$ & $\begin{array}{l}\text { positive on }+30-40 \text { days }\left(<10^{-4}\right) \text {; } \\
\text { MRD clearance, rejection; } \\
\text { MRD reappearance }\left(2.25^{*} 10^{-6}-10^{-5}\right) \\
\text { on }+519-736 \text { days }\end{array}$ & $\begin{array}{l}\text { yes, after }+60 \\
\text { day; } \\
\text { after }+839 \text { day }\end{array}$ & no & no & $\begin{array}{l}\text { Increasing } \\
\text { MC/0\% }\end{array}$ & $\begin{array}{l}\text { alive (5 years), } \\
\text { rejection on } \\
+74 \text { day }\end{array}$ \\
\hline 6 & $<10^{-4}-4^{\star} 10^{-4}$ & $\begin{array}{l}\text { yes; negative on }+30 \text { day, from } \\
+60 \text { day growth and persistence } \\
\text { of MRD }\end{array}$ & $\begin{array}{l}\text { temporary } \\
\text { after DLI }\end{array}$ & yes & no/no & FDC & TRM (332 day) \\
\hline 7 & $<10^{-4}$ & $\begin{array}{l}\text { yes; negative on }+30 \text { day, positive } \\
\text { on }+60 \text { days }\left(<10^{-4}\right) \text {; DLI, clearance }\end{array}$ & yes, after DLI & yes & no/no & $\mathrm{FDC}$ & alive (341 days) \\
\hline 8 & $2.7 * 10^{-2}$ & 1 point before relapse & no & no & no & Increasing MC & $\begin{array}{l}\text { BM relapse (66 } \\
\text { day); death (221 } \\
\text { day) }\end{array}$ \\
\hline 9 & $2.2^{*} 10^{-2}$ & 1 point before relapse & no & no & no & MC (1 point) & $\begin{array}{l}\text { BM relapse } \\
\text { (54 day); death } \\
\text { (109 day) }\end{array}$ \\
\hline 10 & $1.2^{*} 10^{-3}-3^{*} 10^{-3}$ & $\begin{array}{l}\text { yes; decrease and clearance of } \\
\text { MRD after IDL; then increase up } \\
\text { to } 2^{\star} 10^{-3}\end{array}$ & $\begin{array}{l}\text { temporary } \\
\text { after DLI }\end{array}$ & yes & $\begin{array}{l}\text { after } \\
\text { DLI }\end{array}$ & $\begin{array}{l}\text { Increasing MC } \\
\text { (temporary } \\
\text { FDC after DLI) }\end{array}$ & $\begin{array}{l}\text { BM relapse } \\
\text { (368 day); } \\
\text { death (671 day) }\end{array}$ \\
\hline 11 & $2 * 10^{-4}-2.7 * 10^{-4}$ & $\begin{array}{l}\text { yes; positive on }+30 \text { day, negative } \\
\text { on }+47 \text { and }+82 \text { days, positive on } \\
+93 \text { day }\end{array}$ & temporary & no & no & Increasing MC & $\begin{array}{l}\text { BM relapse (124 } \\
\text { day); death (184 } \\
\text { day) }\end{array}$ \\
\hline 12 & $1,8 * 10^{-5}-2,9 * 10^{-3}$ & $\begin{array}{l}\text { yes; negative till +123 day, MRD } \\
\text { growth with unclear dynamics } \\
\text { (positive and negative points) }\end{array}$ & $\begin{array}{l}\text { temporary } \\
\text { after DLI }\end{array}$ & yes & $\begin{array}{l}\text { after } \\
\text { DLI }\end{array}$ & FDC & $\begin{array}{l}\text { BM relapse } \\
\text { (552 day); lost } \\
\text { follow up }\end{array}$ \\
\hline 13 & $10^{-3}-1.6^{*} 10^{-1}$ & $\begin{array}{l}\text { yes; positive on }+30 \text { day, negative } \\
+60 \text { day, then MRD growth }\end{array}$ & temporary & no & no/no & FDC & $\begin{array}{l}\text { BM relapse } \\
\text { (226 day); death } \\
\text { (384 day) }\end{array}$ \\
\hline 14 & $10^{-2}$ & 1 point (on +30 day) & - & no & no/no & Increasing MC & $\begin{array}{l}\text { BM relapse } \\
\text { (365 day); } \\
\text { death (419 day) }\end{array}$ \\
\hline
\end{tabular}

$\left({ }^{* *}\right)$ - on the background of GvHD

$(* *)$ - after GvHD 
discordant, i.e., the abovementioned patient who was negative by Ig/TCR target (loss of the target), but he was positive for $M L L-A F 4$. In four patients, MRD was not detected, either by expression of $B C R-A B L 1(\mathrm{n}=2), M L L-A F 4(\mathrm{n}=2)$, or Ig/TCR targets. Positive MRD was detected by both methods in four patients. Paired points for comparison were available in two patients. In one case, positive MRD was detectable by both approaches ( $M L L-A F 4$ and Ig/TCR markers). In another case (patient №12), we observed earlier appearance of $\mathrm{MRD}$ in $\mathrm{BM}$ as detected by TEL-AML expression (on day +98 ), than by Ig/TCR marker (detected at the next point of $\mathrm{D}+124)$. Hence, the first method seems to be more sensitive (Fig. 3).

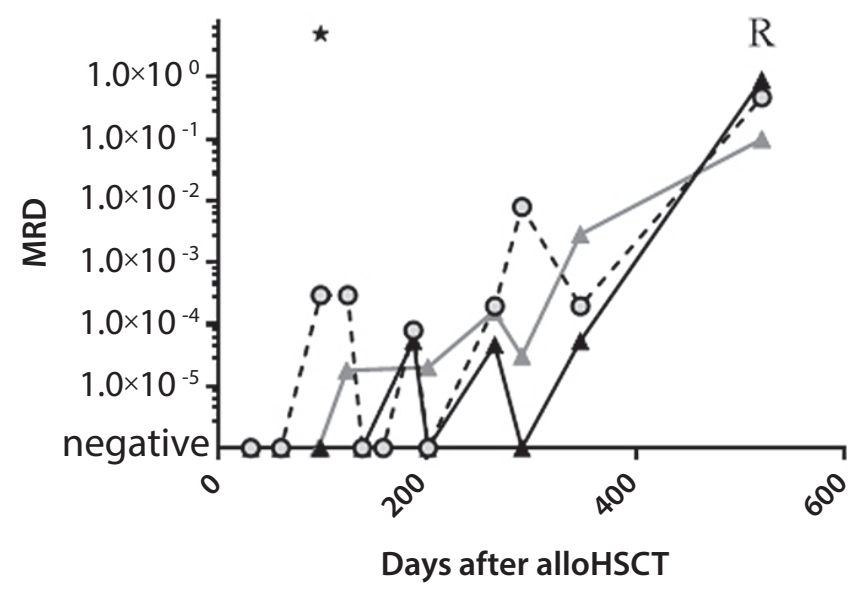

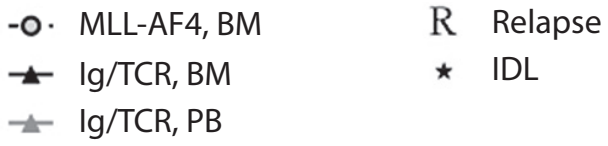

Figure 3. MRD time course in Patient \#12, according to TEL-AML expression and Ig/TCR rearrangement (lgk). Abscissa, gene copy number $\left(\log _{10}\right)$; ordinate, terms posttransplant
MRD measured by immunophenotyping and Ig/TCR rearrangements was monitored in four patients in parallel (at the same time points after HSCT). Negative MRD was detected by both methods in one patient. In three patients, we received discordant results: there were positive MRD values of $<10^{-3}$ detected by Ig/TCR gene rearrangements, however, being negative by immunophenotyping technique. Nevertheless, negative results were observed in some cases by both methods.

\section{Comparison of MRD data obtained by lg/TCR and chimerism markers}

Donor chimerism monitoring was performed in all 35 patients.

1) Full donor chimerism (FDC) and negative MRD state were detected in 19 patients, only 2 of them have relapsed (Table $3)$. In one patient with loss of Ig/TCR target, a relapse was diagnosed more than 2 months after last chimerism monitoring in BM cells ( $\mathrm{D}+377$, late isolated BM relapse). The second patient with extramedullary CNS relapse had negative MRD and FDC in PB and BM cells, even at the time of relapse.

2) Mixed chimerism (MC) and negative $M R D$ were detectable in 2 cases. One patient had negative MRD and MC (98.9\%) in $\mathrm{BM}$ on $\mathrm{D}+30$. This patient reached FDC (since +60 day), but died with infectious complications on $\mathrm{D}+542$. The second patient showed FDC conversion to increasing MC accompanied by infection, and died on $\mathrm{D}+78$.

3) FDC and positive MRD (up to $1.6^{\star} 10^{-1}$ ) was observed in 7 patients, two of them have relapsed. The patient №12 had BM relapse on $\mathrm{D}+522$, with last testing point at $\mathrm{D}+347$, when full donor chimerism and MRD of $5^{\star} 10^{-5}$ were determined. In the second patient (№13), a BM relapse was diagnosed by the D+226. Slightly decreased chimerism level of $99.1 \%$ was registered in blood leukocytes, along with increased MRD level to $15 \%$ at the last term before the relapse (D+197). In three patients with FDC, we observed MRD clearance, the rest of them retained their MRD positivity at the last examination.

Table 3. Comparison of MRD and chimerism monitoring data in ALL patients

\begin{tabular}{|c|c|c|c|}
\hline & & & Chimerism \\
\hline & & $\begin{array}{l}F D C \\
n=26\end{array}$ & $\begin{array}{l}C X \\
n=9\end{array}$ \\
\hline MRD & $\begin{array}{l}\text { Negative } \\
\mathrm{n}=21\end{array}$ & $\begin{array}{l}n=19 \\
2 \text { relapses } \\
17 \text { alive }\end{array}$ & $\begin{array}{l}\mathrm{n}=2 \\
\text { * decreasing MC/FDC (n=1) } \\
\text { * increasing MC (n=1) } \\
0 \text { relapses } \\
0 \text { alive } \\
\end{array}$ \\
\hline & $\begin{array}{l}\text { Positive } \\
\mathrm{n}=14\end{array}$ & $\begin{array}{l}\mathrm{n}=7 \\
2 \text { relapses } \\
3 \text { alive } \\
1 \text { lost follow up }\end{array}$ & $\begin{array}{l}n=7 \\
\text { *decreasing } M C / F D C(n=1) \\
\text { *increasing } M C(n=5) \\
\text { * } M C-1 \text { point of } M C(n=1) \\
5 \text { relapses } \\
1 \text { rejection } \\
2 \text { alive }\end{array}$ \\
\hline
\end{tabular}


4) $M C$ and positive MRD was traced in seven patients, five of them had the disease recurrence. Before relapse, an increase of MC and MRD up to $2.2^{\star} 10^{-2}$ was observed in four patients (the fifth patient had an early relapse, and only one monitoring point before relapse). Patient №5 with increasing $\mathrm{MC}$ has shown graft rejection on $\mathrm{D}+74$ with subsequent autorecovery without ALL reoccurrence, with MRD levels in BM of $<10^{-4}$ on days +27 to +39 , then becoming negative at later terms. Patient №1 had an MC state $(98.5 \%$ on $\mathrm{D}+30$ in BM and PC) with FDC state achieved by the $\mathrm{D}+60$; this patient is now alive, being in complete remission.

Thus, we have revealed sufficient concordance between MRD and donor chimerism in $26(74.3 \%)$ out of 35 cases. The most favorable group comprised a subgroup with negative MRD and FDC, an intermediate group consisted of patients with positive MRD and FDC, and the most unfavorable group included the patients with positive MRD and increasing MC. The respective 3-year CI of relapse for these groups were as follows: $11.9 \pm 8.2 \%$ vs $41.7 \pm 29.5 \%$ vs $80.0 \pm 23.9 \%$ $(\mathrm{p}<0.0008)$; the OS values were $94.4 \pm 5.4 \%$ vs $44.4 \pm 22.2 \%$ vs $20.0 \pm 17.9 \%(\mathrm{p}=0.0029)$; EFS probability was $75.0 \pm$ $11.0 \%$ vs $25.0 \pm 20.4 \%$ vs $0 \%$ ( $<<0.0001)$, respectively (Fig. 4).

\section{Dependence of survival upon MRD and GVHD association}

Grade I-IV acute GvHD (aGvHD) was observed in 17 $(48.6 \%)$ of 35 patients, and six of them were diagnosed with severe aGvHD (grade III-IV). MRD-negative state was registered more often in the patients with aGvHD (in 13 of 17 cases), as compared to the GvHD-free cases ( 8 of 18 patients, $\mathrm{p}=0.085$ ).

1) Among 13 patients with negative $M R D$ and $a G v H D$, only $1(7.7 \%)$ patient had relapse in CNS.

2) Among eight patients with negative MRD without aGvHD, nobody has relapsed.

3) None of the four patients with positive MRD and aGvHD relapsed. MRD clearance occurred in 4 patients (40\%) on the days $+100-+150$.

4) In seven (70\%) of 10 patients with positive MRD without $a G v H D$ disease reoccurred. Four of these 10 patients received DLI, 2 of them experienced relapse despite GvHD signs observed after IDL.

Clinical outcomes of the patients with negative MRD without aGvHD, patients with negative MRD with aGvHD, and patients with positive MRD and aGvHD were nearly similar, being definitely better than in the group of aGvHD-free patients with positive MRD. The three-year CI of relapse rates were as follows: $20.0 \pm 20.0 \%$ vs $7.7 \pm 7.7 \%$ vs $0 \%$ vs $80.0 \pm 20.2 \%(\mathrm{p}=0.008)$. The respective, overall survival probability was $80.0 \pm 17.9 \%$ vs $84.6 \pm 10.0 \%$ vs $66.7 \pm 27.2 \%$ vs $18.0 \pm 15.1 \%(\mathrm{p}=0.026)$. The EFS values for these subgroups were: $60.1 \pm 21.9 \%$ vs $67.3 \pm 13.6 \%$ vs $66.7 \pm 27.2 \%$ vs $0 \%$ $(\mathrm{p}=0.0004)$, respectively (Fig. 5).

\section{Discussion}

The MRD monitoring can help to identify presence of tumor cells that survived after the conditioning. However, this
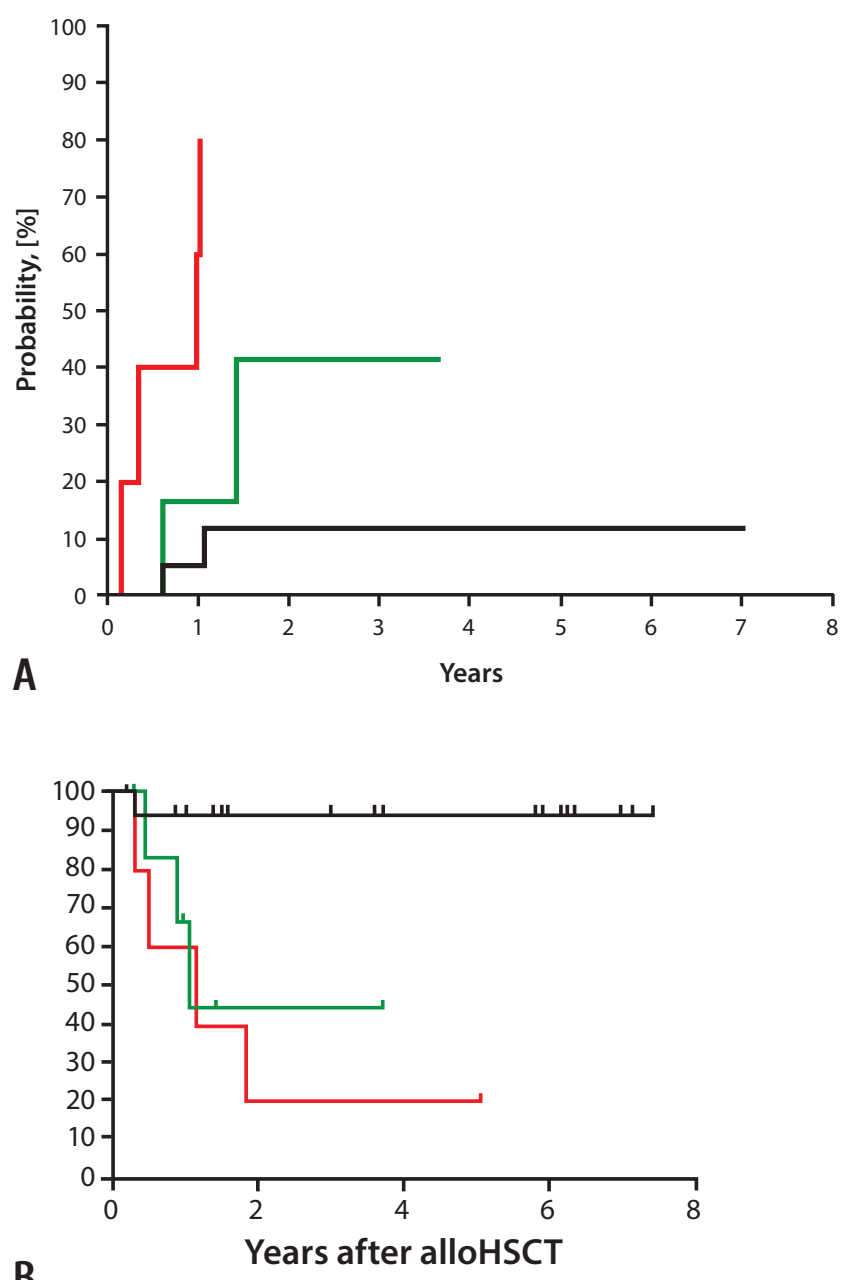

B

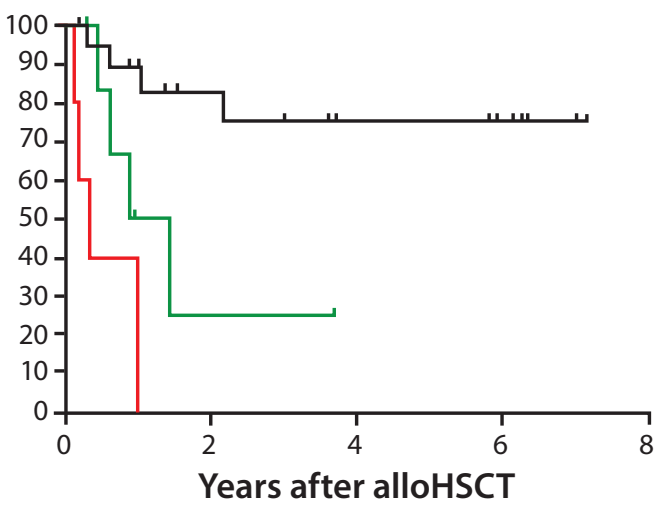

C

Figure 4. Probability of relapse (A), OS (B) and EFS (C) in patients with ALL/biphenotypic AL according to MRD and chimerism after allo-HSCT. Curves are designated black (MRD+/FDC); green (MRD+/FDC); or red (MRD-/ mixed chimerism increase) 


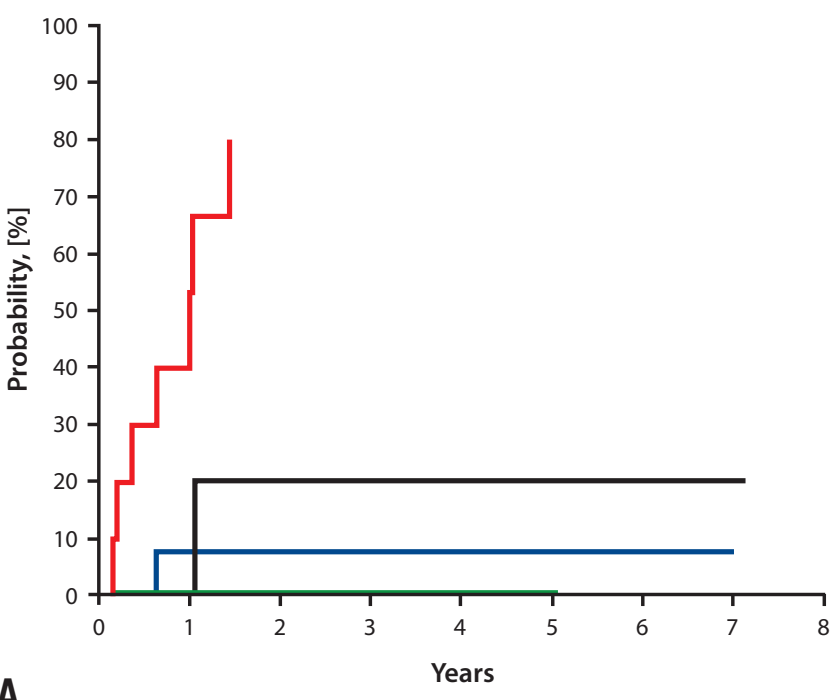

A

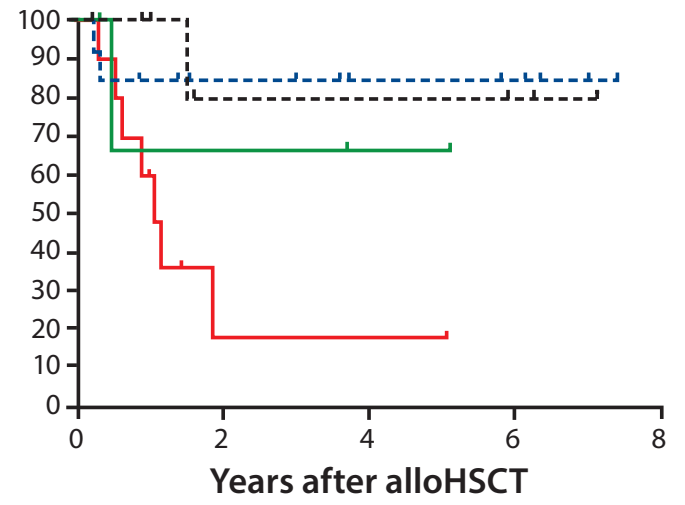

B

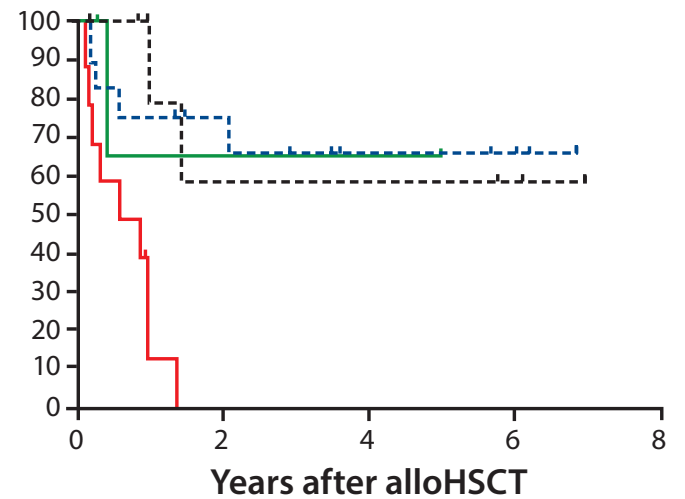

Figure 5. Probability of relapse (A), OS (B) and EFS (C) in patients with ALL/biphenotypic AL according to MRD and chimerism after allo-HSCT. Curves are designated black (MRD-/no GVHD); blue (MRD-/aGVHD); red (MRD+/ no aGVHD); or green (MRD+/aGVHD) assay is applicable only for patients with a defined marker (chimeric oncogenes, mutations, Ig/TCR rearrangements or leukemia-associated immunophenotype). Identification of tumor-specific mutations is the most accurate diagnostic approach showing high specificity. However, the structure of these mutations should be suitable for MRD monitoring, with a sensitivity of, at least, $10^{-4}$ [36]. In ALL monitoring, quantitative real-time PCR (qPCR) allows to determine MRD by specific chimeric oncogenes/transcripts, point mutations and other rearrangements, such as $B C R-A B L 1, P M L /$ RARa, RUNX1-RUNX1T1 (AML1-ETO), CBFB-MYH11, $M L L$ translocations, at a high sensitivity of $10^{-5}-10^{-6}$ [37]. Chimeric oncogenes are detected only in a small number of patients with ALL $[36,38]$. In our study, they were found only in $11 \%$ of transplantation patients. There exists another alternative to chimeric oncogenes and mutations in ALL, i.e., clonal rearrangements of Ig and TCR genes, which are an attractive marker for MRD monitoring, being detectable in vast majority of ALL patients (up to $90-95 \%$ [36,37], $82 \%$ of our patients).

Analytical sensitivity is an important aspect of MRD assay, since an arising leukemic clone posttransplant is regarded as an unfavorable event. MRD monitoring with Ig/TCR has a good sensitivity up to $10^{-4}-10^{-5}$. Measurement of chimeric oncogene expression may be an even more sensitive approach in some cases, since a single malignant cell may contain several dozens or even thousands copies of chimeric oncogenes. It increases sensitivity up to $1 \lg _{10}$, thus allowing earlier detection of tumor cells after allo-HSCT than with DNA-targets. However, the predictive value of individual methods and expression markers is not well defined. By contrast, MRD monitoring procedure with Ig/TCR rearrangements has been standardized and provides comparable results obtained from different patients, which makes it possible to assess not only the presence of MDR after alloHSCT, but also takes its levels into account $[4,36,37,39]$. Immunophenotyping using flow cytometry has a lower sensitivity (up to $10^{-4}$ ) than PCR-based methods. Its application for MRD monitoring after allo-HSCT is limited due to difficulties with interpretation of results [40]. Bone marrow regeneration after allo-HSCT makes it difficult to identify leukemic cells on the background of normal lymphoid precursors [1].

It is also necessary to consider the stability of various MRD markers [36]. In rare cases, the Ig/TCR target can be lost due to somatic mutations accumulating in tumor cells $[41,42]$, what we have found in one case (2.9\% of total group).

RQ-PCR measuring of Ig/TCR rearrangements provides suitable sensitivity and specificity, being, however, complicated by high costs of the assay, delayed purchasing of ASO, and loss of a gene target in rare cases. However, this method has been accepted in Europe as a standard approach to MRD monitoring [1].

Chimerism assays are used for assessing donor cell engraftment, but they also can be applied for relapse prediction. The study of chimerism by InDel-PCR has a sensitivity of $10^{-4}[30,32]$, but up to $1 \%$ of the recipient cells, even after myeloablative conditioning, may be normally present in BM and PB after allo-HSCT $[43,44]$. Therefore, the sensitivity of donor chimerism for prediction of relapses is limited to $10^{-2}$. 
In addition, the chimerism monitoring is a non-specific method, since the persistent residual cells of recipient origin can be either normal hematopoietic or malignant cells, or both.

MRD monitoring allows identifying the ALL patients being at high risk for relapses after alloHSCT. It was shown in ALL patients that the level of MRD before transplantation significantly affects the result of posttransplant outcome [4, 40, 45-52]. Not all patients with negative MRD pre-transplant remain relapse-free at later terms, as well as not all patients with positive MRD relapse after HSCT. Therefore, the measurement of MRD post-HSCT is another powerful tool, with a potential for more precise relapse prediction. A limited number of trials has explored the role of MRD assays in the post-HSCT period [1]. Post-HSCT positive MRD strongly associated with high risk of relapse and low survival in childhood ALL [4, 40, 50, 52-55]. The presence of detectable MRD after transplant was independent of other factors, including pre-HCT MRD and aGVHD status [40].

In our study, the presence of MRD after allo-HSCT significantly increased the probability of disease recurrence and led to poor overall and event-free survival. We showed that the risk of relapse was increased only in the patients with high MRD levels ( $>10^{-3}$, CI of relapse is $\left.100 \%\right)$, whereas risk of relapse did not differ for the patients with MRD $\leq 10^{-3}$ and with negative MRD, (CI of relapse $11 \%$ and $15 \%$ accordingly). Similarly, Balduzzi et al. have shown that the patients who had high MRD $>10^{-3}$ at any time point post-HSCT, did relapse, despite any attempts to prevent the recurrence of disease [54]. Most patients relapsed with MRD level of $>10^{-}$ ${ }^{3}$, but the patients with MRD $<10^{-3}-10^{-4}$ were more likely to clear their leukemia cells $[52,54,56]$. By contrast, the study of Bader et al. [53] has shown that any level of MRD after allo-HSCT did increase risk of relapse, even MRD $<10^{-4}$, if compared to MRD-free patients on $\mathrm{D}+60,+90$ and +180 , but not on +30 days, and the same results were reported by Zhao group [55]. However, our data and results from other authors $[52-54,56]$ suggest that the patients with low posttransplant MRD levels $<10^{-3}-10^{-4}$ do not necessarily relapse, and additional risk stratification is needed.

Despite recommendations on monitoring of MRD and chimerism for relapse prediction of ALL after alloHSCT, there are only few studies comparing these two methods $[20,56$, 57], and the results of these studies do not give a complete answer as to how a combination of these approaches can improve relapse prediction. We have obtained concordant results between MRD and chimerism in $74 \%$ cases. Standard methods for determining MPD are of $>1 \lg _{10}$ more sensitive, than the methods for chimerism detection. The main difference between these two approaches is that MRD monitoring directly determines the residual tumor cells and the chimerism analysis gives only information about the persistence/ recoverye of autologous hematopoiesis. Reappearance of recipient cells may indicate the establishment of immunological tolerance thus potentially leading to a weaker immunological surveillance of malignant cells and the development of relapse [58]. Rarely, stable mixed chimerism in some patients with malignant diseases may persist for up to 20 years after alloHSCT, and it does not lead to relapse or rejection [59], although this is rather an exception to the rules. In the majority of cases, the onset of increasing mixed chimerism precedes disease recurrence [19, 20, 32, 60-62].

In our study, a combination of these two diagnostic approaches makes it possible to stratify patients into groups of high, intermediate and low risk of relapse with a very high accuracy. The most favorable group was presented by the patients with negative MRD and FDC with a good OS (94\%) and EFS (75\%), and a low incidence of relapse (12\%). The presence of MRD combined with increasing MC led to the development of relapses in almost all patients (CI relapse $80 \%)$ and significantly worse OS (20\%) and EFS (0\%). In the presence of FDC, some patients showed MRD clearance and became MRD-negative, but this group of patients still had relatively high risk of relapse (CI relapses $42 \%$ ) and intermediate OS (44\%) and EFS values (25\%). Patients could clear their MRD by an immunologic graft-versus-leukemia (GvL) effect, but MRD must be cleared until the establishment of graft tolerance towards the recipient; otherwise, uncontrolled proliferation of residual leukemia cell finally results in hematological relapse [54]. The patients with positive MRD in late posttransplant period are shown to relapse more readily, when compared to patients with MRD positivity over the first 1-2 months [53-56]. During the initial phase after allo-HSCT (within the first 2 months), immunologic reconstruction is incomplete, and GvL effect is not fully exhibited [55]. Our study also confirms the theory of immunological tolerance, because MRD clearance was more often observed in patients with FDC and GvHD, or after DLI. None of the patients with positive MRD developed bone marrow relapse in the presence of GvHD, in contrast to patients with no GVHD (CI relapse $80 \%$ ). The role of the GvL effect is supported by studies showing that the ALL patients who experience GvHD have a lower risk of relapse $[40,49,56]$. As a rule, these three parameters (MRD, GVHD and chimerism) are interrelated. Detection of MC was often combined with positive MRD and lack of GVHD. Absence or reduction of MRD was observed in the patients with FDC and GVHD development.

We have shown that the combination of MRD and chimerism monitoring allows stratification of ALL patients into the groups of relapse risk. In contrast to previous studies [54, 56], we were able to find out prognostic value of increasing $\mathrm{MC}$ due to application of sensitive PCR-based method of chimerism detection and testing of BM samples, along with $\mathrm{PB}$ cells. Our study demonstrates the combined effect of MRD, chimerism and GVHD on the outcomes in allo-HSCT patients.

A serious issue is associated with development of extramedullary relapses which are underdiagnosed because they can manifest with no detectable MRD and in FDC state in the presence of GVHD, even in relapse burden $[56,63]$. There is also a risk to miss early signs of relapse, if the monitoring intervals for the marrow chimerism and MRD exceed 2 months. We recommend monitoring BM at least once or twice a month over first 6-12 months after alloHSCT, when the risk of relapse is high, especially for the patients with previous positive MRD and/or MC, and absence of GVHD signs.

Like other workers, we observed that, in patients with MRD level of $<10^{-3}$, the clearance of malignant clone can be 
achieved with preventive immunotherapy $[54,64]$. In view of these considerations, MRD combined with chimerism could be used as a tool to guide posttransplant pre-emptive immunomodulation or immunotherapy, in order to prevent a disease relapse.

\section{Conclusion}

The presence of positive MRD after allo-HSCT is known to be an unfavorable prognostic factor associated with relapses, poor overall and decreased event-free survival. In patients with ALL, the presence of MRD after allo-HSCT is not always associated with development of relapses. The manifestation of the GvL effect can be observed in patients with FDC and GvHD or after DLI. The patients of a high-risk group for relapse include those with high MRD level $>10^{-3}$, as well as the patients in whom the presence of MRD is combined with increasing mixed chimerism and/or absence of GVHD. Monitoring of MRD in bone marrow does not always allow us to detect extramedullary relapses.

\section{Acknowledgements}

The authors report no conflicts of interest.

\section{References}

1. Lamble A, Phelan R, Burke M. When Less Is Good, Is None Better? The Prognostic and Therapeutic Significance of Peri-Transplant Minimal Residual Disease Assessment in Pediatric Acute Lymphoblastic Leukemia. J Clin Med. 2017;6(7):E66.

2. Barrett AJ, Battiwalla M. Relapse after allogeneic stem cell transplantation. Expert Rev Hematol. 2010;3(4):429-441.

3. Center for International Blood and Marrow Transplant Research [Electronic resource] : Pasquini M, Zhu X. Current uses and outcomes of hematopoietic stem cell transplantation: CIBMTR Summary Slides, 2015. - Mode of access: http://www.cibmtr.org.2015 - Date of access: 05.10.2016

4. Lovisa F, Zecca M, Rossi B, Campeggio M, Magrin E, Giarin E, Buldini B, Songia S, Cazzaniga G, Mina T, Acquafredda G, Quarello P, Locatelli F, Fagioli F, Basso G. Pre- and post-transplant minimal residual disease predicts relapse occurrence in children with acute lymphoblastic leukaemia. $\mathrm{Br}$ J Haematol. 2018;180(5):680-693.

5. Porter DL, Alyea EP, Antin JH, DeLima M, Estey E, Falkenburg JH, Hardy N, Kroeger N, Leis J, Levine J, Maloney DG, Peggs K, Rowe JM, Wayne AS, Giralt S, Bishop MR, van Besien K. NCI First International Workshop on the Biology, Prevention, and Treatment of Relapse after Allogeneic Hematopoietic Stem Cell Transplantation: Report from the Committee on Treatment of Relapse after Allogeneic Hematopoietic Stem Cell Transplantation. Biol Blood Marrow Transplant. 2010;16(11):1467-1503.

6. Labelle, J. L. Stem Cell Transplant As an Immunomodulatory Tool for Children with Hematologic Malignancies / J. L. Labelle, J. M. Cunningham // American Society of Clinical Oncology Educational Book : ed. book / editor Don S. Dizon. - Alexandria, 2014. - P. 347-352.
7. Semenova EV, Stancheva NV, Alyanskyi AL, Babenko EV, Vavilov VN, Morosova EV et al. Allogeneic hematopoietic stem cell transplantation with reduced-intensity conditioning regimens in children and adults with prognostically unfavorable forms of acute lymphoblastic leukemia. Oncohematologyia. 2011; 6(4):19-26 (In Russian).

8. Tracey J, Zhang MJ, Thiel E, Sobocinski KA, Eapen M. Transplantation Conditioning Regimens and Outcomes after Allogeneic Hematopoietic Cell Transplantation in Children and Adolescents with Acute Lymphoblastic Leukemia. Biol Blood Marrow Transplant. 2013;19(2):255-259.

9. Mielcarek M, Storer BE, Flowers ME, Storb R, Sandmaier BM, Martin PJ. Outcomes among Patients with Recurrent High-Risk Hematologic Malignancies after Allogeneic Hematopoietic Cell Transplantation. Biol Blood Marrow Transplant. 2007;13(10):1160-1168.

10. Petrovic A, Hale G. Clinical options after failure of allogeneic hematopoietic stem cell transplantation in patients with hematologic malignancies. Expert Rev Clin Immunol. 2011;7(4):515-525.

11. Kröger N, Bacher U, Bader P, Böttcher S, Borowitz MJ, Dreger P, Khouri I, Macapinlac HA, Olavarria E, Radich J, Stock W, Vose JM, Weisdorf D, Willasch A, Giralt S, Bishop MR, Wayne AS. NCI First International Workshop on the Biology, Prevention, and Treatment of Relapse after Allogeneic Hematopoietic Stem Cell Transplantation: report from the Committee on Disease-Specific Methods and Strategies for Monitoring Relapse following Allogeneic Stem Cell Transplantation. Part 1: Methods, acute leukemias, and myelodysplastic syndromes. Biol Blood Marrow Transplant. 2010;16(9):1187-1211.

12. Deol A, Lum LG. Role of donor lymphocyte infusions in relapsed hematological malignancies after stem cell transplantation revisited. Cancer Treat Rev. 2010;36(7):528-538.

13. Rujkijyanont P, Morris C, Kang G, Gan K, Hartford C, Triplett B, Dallas M, Srinivasan A, Shook D, Pillai A, Pui CH, Leung W. Risk-adapted donor lymphocyte infusion based on chimerism and donor source in pediatric leukemia. Blood Cancer J. 2013;3:e137.

14. de Lima M, Porter DL, Battiwalla M, Bishop MR, Giralt SA, Hardy NM, Kröger N, Wayne AS, Schmid C. Proceedings from the National Cancer Institute's Second International Workshop on the Biology, Prevention, and Treatment of Relapse After Hematopoietic Stem Cell Transplantation: part III. Prevention and treatment of relapse after allogeneic transplantation. Biol Blood Marrow Transplant. 2014;20(1):4-13.

15. Rettinger E, Merker M, Salzmann-Manrique E, Kreyenberg H, Krenn T, Dürken M, Faber J, , Huenecke S, Cappel C, Bremm M2, Willasch A, Bakhtiar S, Jarisch A, Soerensen J, Klingebiel T, Bader P. Pre-Emptive Immunotherapy for Clearance of Molecular Disease in Childhood Acute Lymphoblastic Leukem ia after Transplantation. Biol Blood Marrow Transplant. 2017;23(1):87-95.

16. Kröger N, Miyamura K, Bishop MR. Minimal Residual Disease Following Allogeneic Hematopoietic Stem Cell Transplantation. Biol Blood Marrow Transpl. 2011;17(1 Suppl):S94-100. 
17. Nagafuji K, Miyamoto T, Eto T, Kamimura T, Taniguchi S, Okamura T, Ohtsuka E, Yoshida T, Higuchi M, Yoshimoto G, Fujisaki T, Abe Y, Takamatsu Y, Yokota S, Akashi K, Harada $M$. Monitoring of minimal residual disease (MRD) is useful to predict prognosis of adult patients with $\mathrm{Ph}$-negative ALL : results of a prospective study (ALL MRD2002 Study). 2013;6:14.

18. Athale UH, Gibson PJ, Bradley NM, Malkin DM, Hitzler J; POGO MRD Working Group. Minimal Residual Disease and Childhood Leukemia : Standard of Care Recommendations From the Pediatric Oncology Group of Ontario MRD Working Group. Pediatr Blood Cancer. 2016;63(6):973-982.

19. Bader P, Kreyenberg H, Hoelle W, Dueckers G, Handgretinger R, Lang P, Kremens B, Dilloo D, Sykora KW, Schrappe M, Niemeyer C, Von Stackelberg A, Gruhn B, Henze G, Greil J, Niethammer D, Dietz K, Beck JF, Klingebiel T. Increasing Mixed Chimerism Is an Important Prognostic Factor for Unfavorable Outcome in Children With Acute Lymphoblastic Leukemia After Allogeneic Stem-Cell Transplantation: Possible Role For Pre-Emptive Immunotherapy? J Clin Oncol. 2004;22(9):1696-1705.

20. Terwey TH, Hemmati PG, Nagy M, Pfeifer H, Gökbuget N, Brüggemann M, Le Duc TM, le Coutre P, Dörken B, Arnold R. Comparison of chimerism and minimal residual disease monitoring for relapse prediction after allogeneic stem cell transplantation for adult acute lymphoblastic leukemia. Biol Blood Marrow Transplant. 2014;20(10):1522-1529.

21. van Dongen JJ, Langerak AW, Brüggemann M, Evans PA, Hummel M, Lavender FL, Delabesse E, Davi F, Schuuring E, García-Sanz R, van Krieken JH, Droese J, González D, Bastard C, White HE, Spaargaren M, González M, Parreira A, Smith JL, Morgan GJ, Kneba M, Macintyre EA. Design and standardization of PCR primers and protocols for detection of clonal immunoglobulin and T-cell receptor gene recombinations in suspect lymphoproliferations: report of the BIOMED-2 Concerted Action BMH4-CT98-3936. Leukemia. 2003;17(12):2257-2317.

22. Pongers-Willemse MJ, Seriu T, Stolz F, d'Aniello E, Gameiro P, Pisa P, Gonzalez M, Bartram CR, Panzer-Grümayer ER, Biondi A, San Miguel JF, van Dongen JJ. Primers and protocols for standardized detection of minimal residual disease in acute lymphoblastic leukemia using immunoglobulin and T cell receptor gene rearrangements and TAL1 deletions as PCR targets: report of the BIOMED-1 CONCERTED ACTION: investigation of minimal residual disease in acute leukemia. Leukemia. 1999;13(1):110-118.

23. Chim JC, Coyle LA, Yaxley JC, Cole-Sinclair MF, Cannell PK, Hoffbrand VA, Foroni L. The use of $\mathrm{IgH}$ fingerprinting and ASO-dependent PCR for the investigation of residual disease (MRD) in ALL. Br J Haematol. 1996;92(1):104-115.

24. Taube T, Seeger K, Beyermann B, Hanel C, Duda S, Linderkamp C, Henze G. Multiplex PCR for simultaneous detection of the most frequent $\mathrm{T}$ cell receptor-delta gene rearrangements in childhood ALL. Leukemia. 1997;11(11):19781982.

25. Meleshko AN, Lipay NV, Stasevich IV, Potapnev MP. Rearrangements of IGH, TCRD and TCRG genes as clonality marker of childhood acute lymphoblastic leukemia. Exp Oncol. 2005;27(4):319-324.

26. Meleshko AN, Savva NN, Fedasenka UU, Romancova AS, Krasko OV, Eckert C, von Stackelberg A, Aleinikova OV. Prognostic value of MRD-dynamics in childhood acute lymphoblastic leukemia treated according to the MB2002/2008 protocols. Leuk Res. 2011;35(10):1312-1320.

27. van der Velden VH, van Dongen JJ. MRD Detection in Acute Lymphoblastic Leukemia Patients Using Ig/TCR Gene Rearrangements as Targets for Real-Time Quantitative PCR. Methods Mol Biol. 2009;538:115-150.

28. Pongers-Willemse MJ, Verhagen OJ, Tibbe GJ, Wijkhuijs AJ, de Haas V, Roovers E, van der Schoot CE, van Dongen JJ. Real-time quantitative PCR for the detection of minimal residual disease in acute lymphoblastic leukemia using junctional region specific TaqMan probes. Leukemia. 1998;12(12):2006-2014.

29. van der Velden VH, Cazzaniga G, Schrauder A, Hancock J, Bader P, Panzer-Grumayer ER, Flohr T, Sutton R, Cave H, Madsen HO, Cayuela JM, Trka J, Eckert C, Foroni L, Zur Stadt U, Beldjord K, Raff T, van der Schoot CE, van Dongen JJ; European Study Group on MRD detection in ALL (ESG-MRDALL). Analysis of minimal residual disease by Ig/TCR gene rearrangements: guidelines for interpretation of real-time quantitative PCR data. Leukemia. 2007;21(4):604-611.

30. Alizadeh M, Bernard M, Danic B, Dauriac C, Birebent B, Lapart C, Lamy T, Le Prisé PY, Beauplet A, Bories D, Semana G, Quelvennec E. Quantitative assessment of hematopoietic chimerism after bone marrow transplantation by real-time quantitative polymerase chain reaction. Blood. 2002;99(12):4618-4625.

31. Koldehoff M, Steckel NK, Hlinka M, Beelen DW, Elmaagacli AH. Quantitative Analysis of Chimerism after Allogeneic Stem Cell Transplantation by Real-Time Polymerase Chain Reaction with Single Nucleotide Polymorphisms, Standard Tandem Repeats, and Y-Chromosome-Specific Sequences. 2006;81(10):735-746.

32. Lavrinenko VA, Savitskaya TV, Mareiko YE, Aleynikova OV. Quantitative chimerism analysis after allogeneic hematopoietic stem cell transplantation by means of techniques from molecular genetics. Onkohematologiya. 2014; 2:29-36 (In Russian).

33. Kaplan E, Kaplan MP, Meier P. Nonparametric estimation from incomplete observations. Journal of the American Statistical Association. 1958;53(282):457-481

34. Gooley TA, Leisenring W, Crowley J, Storer BE. Estimation of failure probabilities in the presence of competing risks: new representations of old estimators. Stat Med. 1999;18(6):695-706.

35. Gray RG. A class of K-sample tests for comparing the cumulative incidence of a competing rick. The Annals of Statistics. 1988;16(3):1140-1154.

36. van Dongen JJ, van der Velden VH, Brüggemann M, Orfao A. Minimal residual disease diagnostics in acute lymphoblastic leukemia: Need for sensitive, fast, and standardized technologies. Blood. 2015;125(26):3996-4009. 
37. Campana D. Minimal Residual Disease in Acute Lymphoblastic Leukemia. Hematology. 2010:7-12.

38. Brüggemann $\mathrm{M}$, Kotrova $\mathrm{M}$. Minimal residual disease in adult ALL: technical aspects and implications for correct clinical interpretation. Blood Adv. 2017;1(25):2456-2466.

39. Eckert C, Hagedorn N, Sramkova L, Mann G, Panzer-Grümayer R, Peters C, Bourquin JP, Klingebiel T, Borkhardt A, Cario G, Alten J, Escherich G, Astrahantseff K, Seeger K, Henze G, von Stackelberg A. Monitoring minimal residual disease in children with high-risk relapses of acute lymphoblastic leukemia: Prognostic relevance of early and late assessment. Leukemia. 2015;29(8):1648-1655.

40. Pulsipher MA, Carlson C, Langholz B, Wall DA, Schultz KR, Bunin N, Kirsch I, Gastier-Foster JM, Borowitz M, Desmarais C, Williamson D, Kalos M, Grupp SA. IgH-V(D)J NGS-MRD measurement pre- and early post-allotransplant defines very low- and very high-risk ALL patients. Blood. 2015;125(22):3501-3508.

41. Szczepański T, van der Velden VH, Raff T, Jacobs DC, van Wering ER, Brüggemann M, Kneba M, van Dongen JJ. Comparative analysis of T-cell receptor gene rearrangements at diagnosis and relapse of T-cell acute lymphoblastic leukemia (T-ALL) shows high stability of clonal markers for monitoring of minimal residual disease and reveals the occurrence of second T-ALL. Leukemia. 2003;17(11):2149-2156.

42. Szczepański T, Willemse MJ, Brinkhof B, van Wering ER, van der Burg M, van Dongen JJ. Comparative analysis of Ig and TCR gene rearrangements at diagnosis and at relapse of childhood precursor-B-ALL provides improved strategies for selection of stable PCR targets for monitoring of minimal residual disease. Blood. 2002;99(7):2315-2323.

43. Lavrinenko VA, Mareiko YE, Beresovskaya EY, Bydanov OI, Belevtsev MV, Minakovskaya NV, Aleynikova OV. Chimerism dynamics as a prognostic factor for the relapse risk after allogeneic hematopoietic stem cell transplantation in oncohematological diseases. Izvestiya of the Belarus National Academy of Sciences (Ser Med. Sci.). 2017;2:26-40 (In Russian).

44. Lavrinenko VA, Mareiko YE, Kras'ko OV, Beresovskaya EY, Doronina SN, Stegantseva MV, Minakovskaya NV, Belevtsev MV, Aleynikova OV. Outcomes in allogeneic hematopoietic stem cell transplantation in the patients with acute leukemia depends on the chimerism level on D+30. Eurasian J Oncol. 2017;5(3):429-448 (In Russian).

45. Knechtli CJ, Goulden NJ, Hancock JP, Harris EL, Garland RJ, Jones CG, Grandage VL, Rowbottom AW, Green AF, Clarke E, Lankester AW, Potter MN, Cornish JM, Pamphilon DH, Steward CG, Oakhill A. Minimal residual disease status as a predictor of relapse after allogeneic bone marrow transplantation for children with acute lymphoblastic leukaemia. Br J Haematol. 1998;102(3):860-871.

46. Bader P, Hancock J, Kreyenberg H, Goulden NJ, Niethammer D, Oakhill A, Steward CG, Handgretinger R, Beck JF, Klingebiel T. Minimal residual disease (MRD) status prior to allogeneic stem cell transplantation is a powerful predictor for post-transplant outcome in children with ALL. Leukemia. 2002;16(9):1668-1672.
47. van der Velden VH, Joosten SA, Willemse MJ, van Wering ER, Lankester AW, van Dongen JJ, Hoogerbrugge PM. Real-time quantitative PCR for detection of minimal residual disease before allogeneic stem cell transplantation predicts outcome in children with acute lymphoblastic leukemia. Leukemia. 2001;15(9):1485-1487.

48. Bader P, Kreyenberg H, Henze GH, Eckert C, Reising M, Willasch A, Barth A, Borkhardt A, Peters C, Handgretinger R, Sykora KW, Holter W, Kabisch H, Klingebiel T, von Stackelberg A; ALL-REZ BFM Study Group. Prognostic value of minimal residual disease quantification before allogeneic stem-cell transplantation in relapsed childhood acute lymphoblastic leukemia: the ALL-REZ BFM Study Group. J Clin Oncol. 2009;27(3):377-384.

49. Sutton R, Shaw PJ, Venn NC, Law T, Dissanayake A, Kilo T, Haber M, Norris MD, Fraser C, Alvaro F, Revesz T, Trahair TN, Dalla-Pozza L, Marshall GM, O'Brien TA. Persistent MRD before and after allogeneic BMT predicts relapse in children with acute lymphoblastic leukaemia. Br J Haematol. 2015;168(3):395-404.

50. Leung W, Pui CH, Coustan-Smith E, Yang J, Pei D, Gan K, Srinivasan A, Hartford C, Triplett BM, Dallas M, Pillai A, Shook D, Rubnitz JE, Sandlund JT, Jeha S, Inaba H, Ribeiro RC, Handgretinger R, Laver JH, Campana D. Detectable minimal residual disease before hematopoietic cell transplantation is prognostic but does not preclude cure for children with very-high-risk leukemia. Blood. 2012;120(2):468472 .

51. Gandemer V, Pochon C, Oger E, Dalle JH, Michel G, Schmitt C, de Berranger E, Galambrun C, Cavé H, Cayuela JM, Grardel N, Macintyre E, Margueritte G, Méchinaud F, Rorhlich P, Lutz P, Demeocq F, Schneider P, Plantaz D, Poirée $\mathrm{M}$, Bordigoni P. Clinical value of pre-transplant minimal residual disease in childhood lymphoblastic leukaemia: The results of the French minimal residual disease-guided protocol. Br J Haematol. 2014;165(3):392-401.

52. Bar M, Wood BL, Radich JP, Doney KC, Woolfrey AE, Delaney C, Appelbaum FR, Gooley TA. Impact of Minimal Residual Disease, Detected by Flow Cytometry, on Outcome of Myeloablative Hematopoietic Cell Transplantation for Acute Lymphoblastic Leukemia. Leuk Res Treatment. 2014: $1-9$.

53. Bader P, Kreyenberg H, von Stackelberg A, Eckert C, Salzmann-Manrique E, Meisel R, Poetschger U, Stachel D, Schrappe M, Alten J2, Schrauder A, Schulz A, Lang P, Müller I, Albert MH, Willasch AM, Klingebiel TE, Peters C. Monitoring of minimal residual disease after allogeneic stemcell transplantation in relapsed childhood acute lymphoblastic leukemia allows for the identification of impending relapse: Results of the all-bfm-sct 2003 trial. J Clin Oncol. 2015;33(11):1275-1284.

54. Balduzzi A, Di Maio L, Silvestri D, Songia S, Bonanomi S, Rovelli A, Conter V, Biondi A, Cazzaniga G, Valsecchi MG. Minimal residual disease before and after transplantation for childhood acute lymphoblastic leukaemia: Is there any room for intervention? Br J Haematol. 2014;164(3):396-408.

55. Zhao XS, Liu YR, Zhu HH, Xu LP, Liu DH, Liu KY, Huang XJ. Monitoring MRD with flow cytometry: an effec- 
tive method to predict relapse for ALL patients after allogeneic hematopoietic stem cell transplantation. Ann Hematol. 2012;91(2):183-192.

56. Pochon C, Oger E, Michel G, Dalle JH, Salmon A, Nelken B, Bertrand Y, Cavé H, Cayuela JM, Grardel N, Macintyre E, Margueritte G, Méchinaud F, Rohrlich P, Paillard C, Demeocq F, Schneider P, Plantaz D, Poirée M, Eliaou JF, Semana G, Drunat S, Jonveaux P, Bordigoni P, Gandemer V. Follow-up of post-transplant minimal residual disease and chimerism in childhood lymphoblastic leukaemia: $90 \mathrm{~d}$ to react. Br J Haematol. 2015;169(2):249-261.

57. Preuner S, Peters C, Pötschger U, Daxberger H, Fritsch G, Geyeregger R, Schrauder A, von Stackelberg A, Schrappe M, Bader P, Ebell W, Eckert C, Lang P, Sykora KW, Schrum J, Kremens B, Ehlert K, Albert MH, Meisel R, Lawitschka A, Mann G, Panzer-Grümayer R, Güngör T, Holter W, Strahm B, Gruhn B, Schulz A, Woessmann W, Lion T. Risk assessment of relapse by lineage-specific monitoring of chimerism in children undergoing allogeneic stem cell transplantation for acute lymphoblastic leukemia. 2016;101(6):741-746.

58. Bader P, Stoll K, Huber S, Geiselhart A, Handgretinger R, Niemeyer C, Einsele H, Schlegel PG, Niethammer D, Beck J, Klingebiel T. Characterization of lineage-specific chimaerism in patients with acute leukaemia and myelodysplastic syndrome after allogeneic stem cell transplantation before and after relapse. Br J Haematol. 2000;108(4):761-768.

59. Levrat E, Roosnek E, Masouridi S, Mohty B, Ansari M, Villard J, Passweg JR, Chalandon Y. Very Long Term Stability of Mixed Chimerism after Allogeneic Hematopoietic Stem Cell Transplantation in Patients with Hematologic Malignancies. Bone Marrow Res. 2015:176526. doi:

60. Bader P, Kreyenberg H, Hoelle W, Dueckers G, Kremens B, Dilloo D, Sykora KW, Niemeyer C, Reinhardt D, Vormoor J, Gruhn B, Lang P, Greil J, Handgretinger R, Niethammer D, Klingebiel T, Beck JF. Increasing mixed chimerism defines a high-risk group of childhood acute myelogenous leukemia patients after allogeneic stem cell transplantation where pre-emptive immunotherapy may be effective. Bone Marrow Transplant. 2004;33(8):815-821.

61. Rettinger E, Willasch AM, Kreyenberg H, Borkhardt A, Holter W, Kremens B, Strahm B, Woessmann W, Mauz-Koerholz C, Gruhn B, Burdach S, Albert MH, Schlegel PG, Klingebiel T, Bader P. Preemptive immunotherapy in childhood acute myeloid leukemia for patients showing evidence of mixed chimerism after allogeneic stem cell transplantation. Blood. 2011;118(20):5681-5688.

62. Zeiser R, Spyridonidis A, Wäsch R, Ihorst G, Grüllich C, Bertz H, Finke J. Evaluation of immunomodulatory treatment based on conventional and lineage-specific chimerism analysis in patients with myeloid malignancies after myeloablative allogeneic hematopoietic cell transplantation. Leukemia. 2005;19(5):814-821.

63. Demirsoy ET, Atesoglu EB, Tarkun P, Gedük A, Erdem BE, Hacihanefioglu A, Erçin MC. Isolated Breast Relapse of Acute Lymphoblastic Leukemia After Allogeneic Hematopoietic Stem Cell Transplantation. Indian J Hematol Blood Transfus. 2016;32(Suppl 1):201-204.
64. Rettinger E, Merker M, Salzmann-Manrique E, Kreyenberg H, Krenn T, Dürken M, Faber J, Huenecke S, Cappel C, Bremm M, Willasch A, Bakhtiar S, Jarisch A, Soerensen J, Klingebiel T, Bader P. Pre-Emptive Immunotherapy for Clearance of Molecular Disease in Childhood Acute Lymphoblastic Leukemia after Transplantation. Biol Blood Marrow Transplant. 2017;23(1):87-95. 


\title{
Мониторинг минимальной остаточной болезни путем RQ-ПЦР перестроек lg/TCR - эффективный метод прогноза рецидивов у детей с острым лим- фобластным лейкозом после аллогенной транс- плантации гемопоэтических стволовых клеток
}

\author{
Виктория А. Лавриненко ${ }^{1}$, Александр Н. Мелешко ${ }^{1}$, Дмитрий В. Луцкович ${ }^{1}$, Юлия Е. Марейко ${ }^{1}$, \\ Дмитрий В. Прудников ${ }^{1}$, Михаил В. Белевцев ${ }^{1}$, Ольга В. Алейникова ${ }^{1}$, Ильдар М. Бархатов ${ }^{2}$, Борис В. Афанасьев ${ }^{2}$ \\ ${ }^{1}$ Республиканский научно-практический центр детской онкологии, гематологии и иммунологии, Минск, Республика \\ Беларусь \\ ${ }^{2}$ НИИ детской онкологии, гематологии и трансплантологии им. Р. М. Горбачевой Первого Санкт-Петербургского \\ государственного медицинского университета им. И. П. Павлова, Санкт-Петербург, Российская Федерация
}

\section{Резюме}

Клинические рецидивы остаются основной причиной неудач в лечении детей с острым лимфобластным лейкозом (ОЛЛ) после аллогенной трансплантации гемопоэтических клеток (алло-ТГСК). К настоящему времени не подтверждена необходимость точной количественной оценки минимальной остаточной болезни (МОБ) после трансплантации. Целью настоящего исследования была оценка вклада диагностики МОБ в тактику лечения и исходы алло-ТГСК.

\section{Пациенты и методы}

Для мониторинга МОБ идентифицировали маркеры Ig/TCR у 37 из 45 больных (82,2\%). Наличие МОБ высокой степени после алло-ТГСК было неблагоприятным прогностическим фактором для клинического исхода. Трехлетняя кумулятивная встречаемость (CI) рецидива заболевания в группах пациентов с негативными результатами оценки МОБ, уровнями МОБ $\leq 10^{-3}$ и $>10^{-3}$ была, соответственно, $10,7 \pm 7,4 \% ; 14,6 \pm 14,6 \%$, и $100 \%$ ( $<<0,0001)$. Бессобытийная выживаемость (EFS) при этом составила $66,6 \pm 11,4 \%$ против $43,8 \pm 18,8 \%$ и $0 \%$, соответственно ( $\mathrm{p}=0,0012)$, тогда как общая выживаемость (ОВ) была $83,6 \pm 8,8 \%$, по сравнению с $57,1 \pm 18,7 \%$ и
$0 \%(\mathrm{p}=0,0083)$ для групп с отсутствием МОБ, при ее уровнях $\leq 10^{-3}$ и $>10^{-3}$. Наличие МОБ в сочетании с повышением уровней смешанного химеризма (CX) сопровождались рецидивами почти во всех случаях. Падение уровней МОБ наиболее часто отмечалось у пациентов с полным донорским химеризмом при наличии реакции «трансплантат против хозяина (оРТПХ) или после переливания донорских лимфоцитов.

\section{Выводы}

Наличие МОБ после ТГСК является фактором неблагоприятного исхода по параметрам общей и бессобытийной выживаемости и ассоциировано с рецидивом ОЛЛ. Мы идентифицировали группу высокого риска рецидивов после алло-ТГСК среди больных ОЛЛ, а именно - пациентов с наличием МОБ и смешанного химеризма и отсутствием РТПХ, и/или больных с уровнями МОБ выше $10^{-3}$.

\section{Ключевые слова}

Острый лимфобластный лейкоз, трансплантации гемопоэтических стволовых клеток, минимальная остаточная болезнь, донорский химеризм, риск рецидивов, 